\title{
Management Strategies and Collaborative Relationships for Sustainability in the Agrifood Supply Chain
}

\author{
Juan Carlos Pérez-Mesa ${ }^{1, * \mathbb{C}}$, Laura Piedra-Muñoz ${ }^{1, * \mathbb{C}}$, Emilio Galdeano-Gómez ${ }^{1} \mathbb{D}$ and Cynthia Giagnocavo ${ }^{2} \mathbb{C}$ \\ 1 Department of Economics and Business, University of Almería (Agrifood Campus of International Excellence, \\ ceiA3, Mediterranean Research Center on Economics and Sustainable Development, CIMEDES), \\ 04120 Almería, Spain; galdeano@ual.es \\ 2 Department of Economics and Business, University of Almería (Agrifood Campus of International Excellence, \\ ceiA3, CIAIMBITAL), 04120 Almería, Spain; cgiagnocavo@ual.es \\ * Correspondence: juancarl@ual.es (J.C.P.-M.); lapiedra@ual.es (L.P.-M.)
}

Citation: Pérez-Mesa, J.C.;

Piedra-Muñoz, L.; Galdeano-Gómez,

E.; Giagnocavo, C. Management

Strategies and Collaborative

Relationships for Sustainability in the Agrifood Supply Chain. Sustainability 2021, 13, 749. https://doi.org/ $10.3390 /$ su13020749

Received: 14 December 2020 Accepted: 11 January 2021 Published: 14 January 2021

Publisher's Note: MDPI stays neutral with regard to jurisdictional clai$\mathrm{ms}$ in published maps and institutional affiliations.

Copyright: $\odot 2021$ by the authors. Licensee MDPI, Basel, Switzerland. This article is an open access article distributed under the terms and conditions of the Creative Commons Attribution (CC BY) license (https:// creativecommons.org/licenses/by/ $4.0 /)$.

\begin{abstract}
The present article proposes a complete framework for supply chain strategy (SCS) analysis that is adapted to the specific characteristics of the agrifood chain, thereby facilitating the management of the former. As a specific case of analysis, the horticultural supply chain, originating in Spain and ending with the European consumer, was analyzed, taking as a reference the marketing companies at origin (mainly social economy companies, that is, cooperatives). In addition, a survey of marketing companies is conducted to possibly determine which explicit cooperative growth strategies may include horizontal and vertical collaboration relationships with other members of the chain. The aim was to analyze with whom the horticultural commercialization company collaborates within the supply chain and the key points of such a collaboration. A model analyzing the influence of collaboration on company performance was also considered. The results reveal that, in recent years, aspects related to quality and health have been surpassed and replaced by the concept of sustainability within a framework of collaboration with customers. Additionally, upstream collaboration has been found to be, in most cases, more profitable than collaboration with customers. In any case, it became evident that there is a need to expand collaboration within the chain by incorporating the supplier of the supplier, with the aim of making the chain more profitable.
\end{abstract}

Keywords: supply chain management; sustainability; transport; facilities; quality; innovation

\section{Introduction}

Supply chain strategy (SCS) must be considered to be the foundation of supply chain management (SCM) in any firm [1]. Studies on SCS often analyze the relationship between the performance and the integration or collaboration between a focal firm and its customers and suppliers. As for a more novel approach, other works have studied the need for "internal" alignment between corporate strategy, supply chain strategy, and supply chain capabilities within the company itself, as a basis for collaboration between the focal firm and its partners [2,3]. This perspective attempts to establish a link between the operations strategy and the broader scope of the supply chain. With regard to this point, it is important to highlight the use of new technologies and new management techniques, such as postponement, as they could mitigate internal conflicts in view of achieving SCS [4]. By integrating both approaches, an SCS describes how a firm can gain competitive advantages through its supply chain capabilities, such as cost efficiency, quality, response speed, and flexibility [5].

The classic concept of SCS divides it into two basic categories (Figure 1): lean and agile [6]. Whereas a lean SCS efficiently accelerates all the supply processes in the chain, an agile SCS focuses on the restructuring of the supply chain in response to uncertain and dynamic circumstances. Recent works continue to emphasize the need to determine which competitiveness ingredients the agile and lean strategies must have in order to favor 
collaboration with members and gain better integration of activities within the company itself [5].

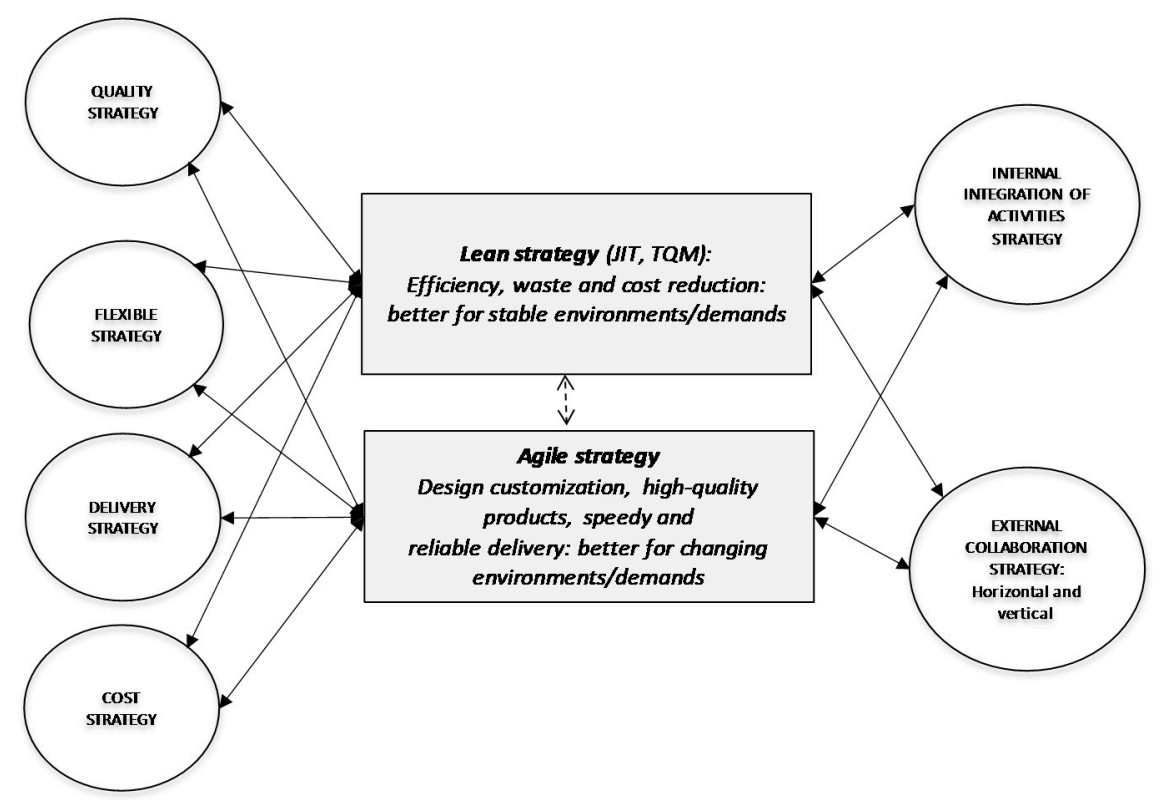

Figure 1. Traditional framework of supply chain strategy analysis. Just-in-time (JIT); total quality management (TQM).

In this framework, the present study considers a more holistic approach in which collaboration with other members in the chain and the internal integration of activities are not endogenous variables within the SCS. Instead, they must be explicitly considered in the strategy and, therefore, in SCM as well. In fact, collaboration strategy must be seen as a unifying element that conditions all other strategies (costs, quality, etc.). One reason why operations strategy is difficult to implement is that there is a large number of functional dependencies [7]. This situation becomes even more complicated in the agrifood chain, in which the producer company sometimes plays a secondary role, depending completely on its members [8,9], ultimately hindering decision-making. With regard to agriculture, the chain's structure itself can have the greatest impact on SCS. What is more, the division between lean and agile systems is blurred, as the strategies adopted are, in many cases, inseparable.

This article proposes a new, complete framework for SCS analysis that is adapted to the specific characteristics of the agrifood chain and facilitates its management. From a theoretical point of view, this is an aspect that has been scarcely addressed in the literature in the case of agricultural products [9]. In this specific case of analysis, the horticultural supply chain originating in Spain and ending with consumers of other European countries was analyzed, taking as a reference the marketing companies at the origin (mainly social economy companies, that is, cooperatives). More specifically, an analysis was conducted to possibly determine which explicit cooperative growth strategies may include horizontal and vertical collaboration relationships with other members of the chain. For this purpose, a survey was designed with the main goal of responding to two questions: (1) With whom is the marketing company collaborating in the supply chain? and, (2) What are the key points of the collaboration? Due to the dominant position of large distribution, it was necessary to analyze its strategy within the chain in order to determine whether the marketing company is in a position to fulfill its demands, which may condition the relationships of cooperation and how specific activities are prioritized. Finally, a model was estimated in order to study the influence of collaboration on company performance.

For the purposes of this research, the present study is structured as follows. Section 2 outlines the agrifood supply chain, analyzing the horizontal and vertical relationships 
within the chain and the main management elements. Then, Section 3 presents the case of study, that is, the Spanish horticulture supply chain, examining the plans of large distribution, the collaborative response of the horticultural marketing company, and the influence of collaboration on company performance. Finally, Section 4 summarizes the main conclusions and future research.

\section{Description of the Agrifood Chain}

The current agrifood market is characterized by varying consumer demands, technology, and socioeconomic factors. In this context, the development of capacities and competitive advantages within a company depends on its management of the supply chain (SC). The SC must be understood as a series of operations that guarantee that goods are produced and distributed in the correct amounts, delivered to chosen locations in the least time possible, with the objective of satisfying the needs of the consumer [10]. The coordination and efficient management of all the companies involved in this process has become a key point to ensure that all members obtain profits in a sector marked by instability and constant changes.

Growers occupy the fundamental position in a network that is responsible for delivering products to the end consumer. The growing trend to concentrate certain phases of the SC (for example, retail distribution or suppliers of seeds, phytosanitary products, and biotechnology) and its increasing internationalization have led small-scale growers to establish organization strategies. In general, this group has tended to rely on a traditional formula for horizontal growth and in a market systems approach, which is the creation of associations in the form of social economy firms. At present, these cooperatives are the most important companies in worldwide food distribution.

Over time, grower organization systems have diversified in terms of role, size, and even terms of association, varying by the country of origin and the product commercialized. Even within one SC itself, large companies with exporting power can coexist with other small ones dedicated to local sales. At the same time, commercial chains can be either long or short. In the first case, intermediate agents are involved until the product reaches the consumer. This group includes members of the agrifood industry, wholesale companies, buying centers, and retailers. In the second case, although the short chain is simpler, it can still include the retailer, therein lying the strategy of important distribution brands for seeking out local suppliers that can offer direct provision (Figure 2). Indeed, this sector features a complex supply network that includes horizontal relationships, which are more common in the production link and involve cooperation with other companies to improve market access and promote coordinated innovation activities. There are also vertical relationships designed to optimize joint processes (e.g., transport, provision, and marketing).

It should be noted that small-scale distribution of agrifood products is subject to a constant restructuring process $[11,12]$. One of the main recent changes is the rise of large distribution as the dominant business model, which considerably modifies relationships in the supply chain [13], thereby affecting the degree of integration and collaboration among its members [14]. In this context, the agrifood supplier of a retailer (normally a cooperative) is a weak link that must adapt if it wants to survive the requirements of its customer $[15,16]$. However, it is important to mention the link prior to the grower, which comprises companies that develop, produce, and sell growers all the necessary inputs (e.g., seeds, biotechnology, fertilizers, and phytosanitary products). These companies, mostly multinationals, are gaining importance, thanks to their high concentration in the supply chain. 


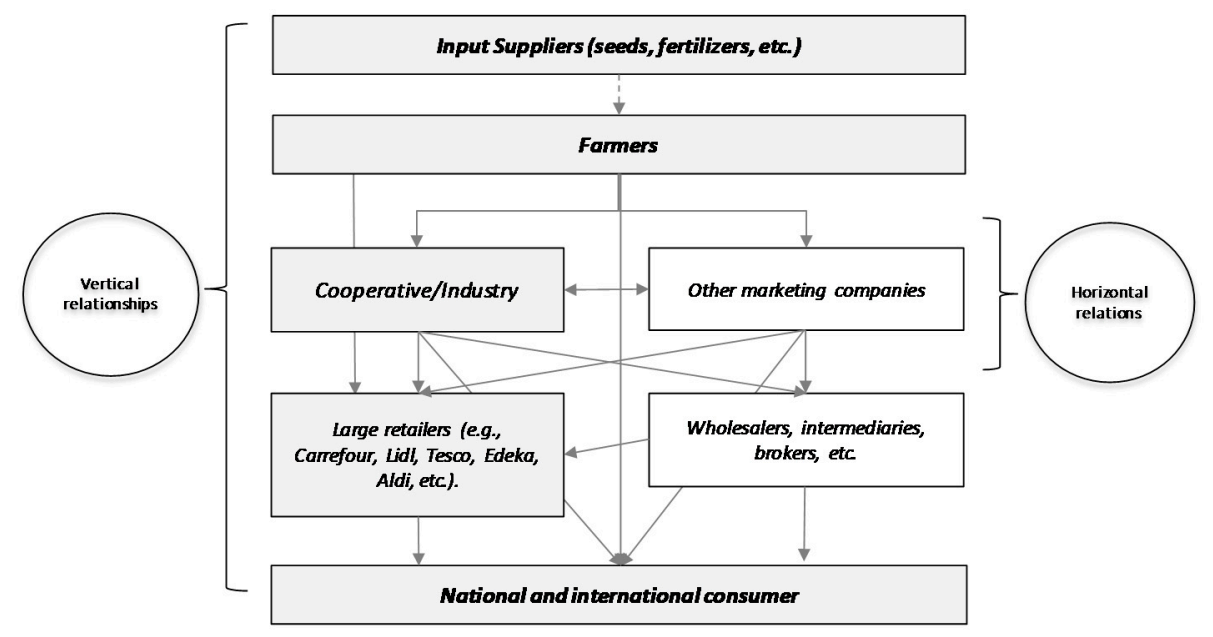

Figure 2. Agrifood supply chain. The gray boxes indicate the priority channel. Source: Own elaboration.

\subsection{Examination of Horizontal and Vertical Relationships within the Chain}

Agrifood companies, as part of the supply chain, must decide on the types of relationships they will build, whether they be vertical or horizontal. For example, they may have to decide which supplier-supplier collaborations are necessary, or what degree of customer integration is appropriate. Therefore, companies need to know the implications of these connections and how their network should be structured in order to obtain a mutual supplier-customer profit. In this sense, the supply chain is basically an inter-organizational network composed of multiple supplier-supplier-customer combinations, in which the improvement of an individual company can only be achieved through the optimization of the entire system [17].

Analysis of collaboration within supply chains follows two basic lines of research. The first focuses only on cooperation in certain areas and the relationships in the chain [18]. The second line considers the phenomenon in its totality, weighing all internal interactions involved in an operational network [19]. However, both lines are compatible [20], as vertical (supplier-buyer) and horizontal (supplier-supplier) relationships and strategies cannot be understood independently without considering the other.

In the case of cooperatives, managing relationships can become complicated due to the existence of a large number of members and their different roles, aspects that should be considered when designing a company strategy within the chain [21]. This approach corresponds to the "netchain concept" [22], understood as the horizontal and vertical network formed by cooperative partner members and their distributors.

In terms of these networks, customer-supplier relationships have been the most widely studied, particularly from the point of view of buyers. In general, companies that collaborate efficiently with suppliers adapt better to unexpected changes; they also identify and implement well-designed solutions to organizational problems and reduce logistics and inventory costs, ultimately improving economic results [23]. While it may seem that these relationships could be rife with conflicts, in fact, that is not the case, as the effects of complementarity are evident. The literature defends the benefits of dividing the supply chain so that suppliers may specialize in actions that favor quality, while customers can focus on promotion and sales [24].

In practice, this collaboration is the first step in an integration process, understood as a better connection and coordination of network members, eventually leading to a higher number of commercial interactions among them [25]. In relation to agricultural products, the notion of integration between the supplier and the retailer can be interpreted in different ways, but it basically implies the creation of alliances that promote the scheduling and reliability of supply by means of establishing long-term relationships, always with the final 
objective of streamlining all processes involved and guaranteeing quality, food safety, and sustainability [26].

One of the characteristics of supply chains is that one of the members, generally the retailer, exerts influence over the rest. This member is known as the "hub company" [27] or "channel master" [28]. In fact, suppliers, in order to maintain their market share, are subject to the requirements of their customers and accept this power imbalance [29]. Furthermore, it is noteworthy that the agricultural supplies link (seeds, biotechnology, fertilizers, and phytosanitary products) has been growing in terms of both activity and power in vertical relationships. This type of company has the power to negotiate with cooperatives, or large retailers, to secure the exclusive use and sale of varieties of products that they have patented.

It is quite interesting that the dynamic of a chain dominated by one or several channel masters can prove inefficient in that it demotivates the rest of the members, for example, regarding actions related to innovation or even marketing. Instead, it would be desirable for the relationship to evolve and eventually create genuine chain organisms [30], in which all companies involved take part in decision making and are intrinsically interdependent in their capacity to act. In fact, this interdependence serves as a source of knowledge for resolving any problem that may arise.

The inclusion of the supplier-supplier relationship within this analytical framework represents an important step towards understanding how the supply chain functions in the context of cooperatives. This is considered the most complex and dynamic relationship of all [16], and it implies the traditional problems of structure and process coordination between companies that compete for the same customers [31]. This could explain why the benefits of this collaboration are not so clear initially [20]. It should be noted that in the supplier-supplier relationship, if the customer is the dominant party, it can play the role of "catalyzer", imposing the collaboration of the suppliers by rewarding or punishing certain behaviors [32]. In any case, it has been demonstrated that horizontal collaboration helps to reduce costs and improve sales through [12] the following: (1) joint participation in companies of greater added value (including R\&D activities for the development of new products); (2) the implementation of quality regulations or standards for the improvement of farming techniques; and (3) joint purchase of inputs to reduce costs (creation of consumption cooperatives).

One point of conflict concerns the degree of integration of the supplier with its customer. In this regard, strategies vary and depend on the advantages and disadvantages of the existence of single or multiple supplier customers. From the point of view of the customer, the advantages of exclusive suppliers are clearer; there's a greater capacity for negotiation, more transparency, more convenient interaction in the relationship, improved investment planning and information exchange, as well as the existence of economies of scale. However, the existence of multiple suppliers also offers advantages: flexibility, price competition among suppliers, and numerous sources of information. At present, most retailers are opting for a mixed solution that involves the integration of suppliers to obtain strategic items, that is, those with higher prices and a complex provision process. In both cases, the supplier, due to its smaller relative size, can find itself in a compromised situation as a result of price reductions [12].

\subsection{Management Elements for the Agrifood Supply Chain}

The member companies of the supply chain must manage certain key aspects to ensure that their products can remain and thrive on the market. Their ability to implement such actions will depend on their capacity for survival. For this reason, it will be useful to analyze the disparities between perishable and non-perishable products supply chains. The main difference lies in the efforts to maintain the quality of merchandise from the start of the chain to its arrival at the point of sale. In the case of perishables, consumers give priority to fresher products with a reasonable price, which implies a fine-tuning of SC management that becomes even more complex if there are intermediaries participating in 
the buying and selling of produce [33,34]. In this context, the existence of a short life-cycle results in significant time reductions in storage and transport processes, even accepting that some losses are inevitable throughout the network [35]. In percentage terms, these losses can be set between $20 \%$ and $60 \%$ of the total volume managed [33]. One way of avoiding this is to provide special treatment to these products at all stages of the chain, carefully evaluating certain aspects that may be handled less rigorously with other merchandise that is less fragile, for example, transport time and flexibility, intermediary storage, and reduction in handling [36]. The general problem of distributing facilities located throughout a wide geographic area with several demand points remains an important research and applied issue. In the case of agrifood distribution, the system does feature a number of shortcomings, and there are even more when it comes to perishables [37]. As a result, it is important for suppliers to maintain a strategy of fast and flexible service [38]. Perhaps suppliers could store produce in advance, based on their estimates and near the final demand, to serve customers as they receive orders.

Another aspect to be considered is the adequate adjustment of production capacity and how it is modified to meet demand. On one hand, production planning [39] means focusing on making products available to the customer on time, a point of conflict in the perishables sector, to avoid price drops that would negatively affect growers' incomes. On the other hand, it implies innovation in a product range or products of higher added value. Regarding transport, it is necessary to evaluate the possibilities and advantages that the available means provide, always weighing their costs, flexibility, and the externalities generated [40,41]. In the case of non-perishable products, the urgency of transport is lower, yet it is still relevant for meeting customers' needs and as a means of compensating for a lack of physical presence near the destination. However, the key to operations management now lies in inventory policy, which is directly linked to production capacity (Figure 3).

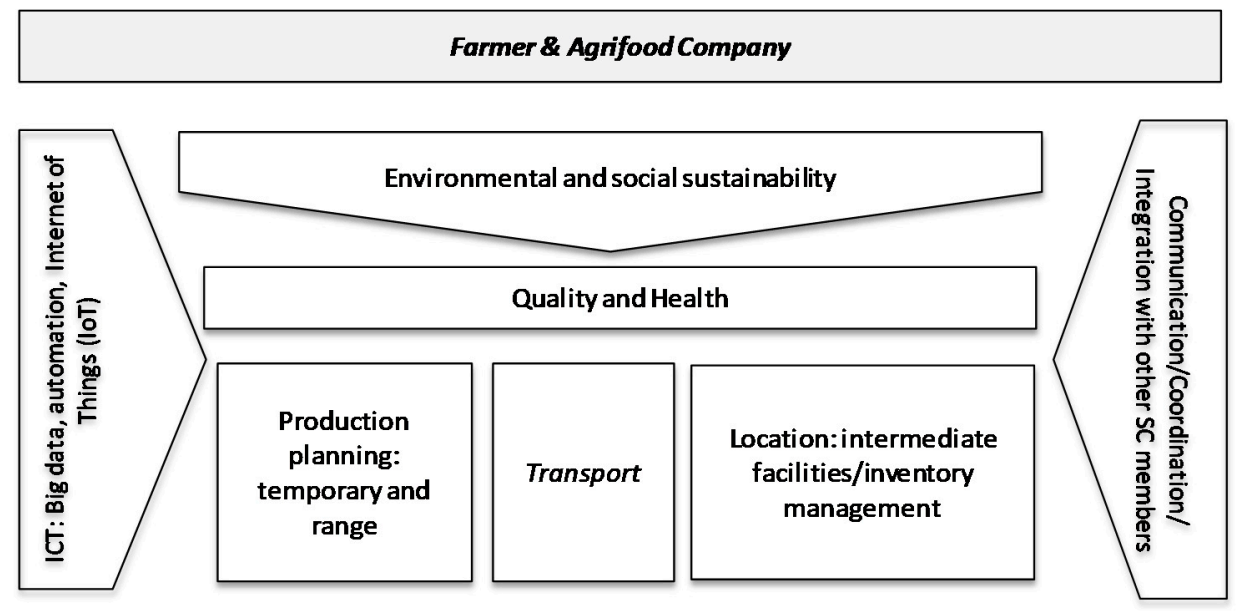

National and international consumer

Figure 3. New strategic analysis framework for agrifood supply chain management (SCM). Source: Own elaboration.

Notwithstanding, sustainability must be considered as the fundamental pillar of any food activity [42]. It is widely regarded as the approach for maintaining an activity in the long term by taking into account the negative externalities (e.g., environmental or social) of the processes within a framework of profitability [43,44]. What is more, sustainability represents a source of competitive advantage insofar as the customer is willing to pay a higher price for products whose elaboration has respected, for example, the environmental and labor conditions $[45,46]$. Similarly, two other concepts, food quality and safety, have occupied the same level of importance, becoming basic requisites for commercialization $[47,48]$. Consequently, retailers are increasingly more demanding with 
suppliers to prevent their brand image from being harmed. Another transversal factor is the combination of communication and coordination in decision making, which implies determining the desired degree of integration [12,49]. For this purpose, integrated and collaborative SCs must be utilized, as they imply transparency among operators seeking to synchronize and simplify activities [50]. The benefits are evident when there is collaboration among members, as it facilitates the execution of efficient processes that reduce costs, thanks to the existence of business synergies resulting from the unification and common use of resources, ultimately leading to increased levels of quality and customer satisfaction [51]. Communication and coordination are also favored by the application of information and communications technologies, as are all other elements of management (sustainability, quality, production planning, transport, and location) [52]. In fact, the digitalization of inter-organizational processes offers an outstanding opportunity for research in the field of operations and supply chain management [53]. The digitalization of the supply chain expands the capacity for analysis and improves the decision-making process, allowing the implementation of strategies based on intelligent management, acquired not only from the experiences of managers but also from reliable data on the performance of production factors [54]. In short, this results in greater efficiency throughout all operations, while also proposing a more intelligent distribution model capable of foreseeing problems and providing a better response time to unexpected events [55]. From the point of view of logistics, the digital transformation of many companies begins with distribution processes, in which technology helps to reduce costs and increase productivity.

\section{Case of Study: Spanish Vegetable Supply Chain}

In recent years, the south of Spain (mainly the provinces of Almería, Granada, and Murcia) has become the principal horticultural supplier in Europe; $40 \%$ of the vegetables consumed in Europe come from Spain. Hence, Spain is considered as the leading European exporter of vegetables (5300 million euros, $70 \%$ of all production), mainly supplying Europe itself. The consumer purchases its products, at least $65 \%$, in commercial establishments from huge distribution chains (e.g., Aldi, Lidl, Carrefour, Edeka, Tesco). Figure 4 reflects the supply chain under analysis, which can be said to consist of several layers (producers-marketers), intermediaries, and large-scale distribution (retailers). As can be observed in the figure, the relationship between the two main marketing companies (cooperatives and auctions) and retailers, either individually or through purchasing centers, dominates the sales to the final consumer.

\subsection{Plans of Large Distribution as the Dominant Company}

For the purpose of analyzing the collaboration activities of horticultural commercialization companies, it was first necessary to identify the strategy that characterizes the hub company or channel master, which in this case, was large European retail. It should be noted that the size of large distributors continues to grow. Recent evidence of this is the agreement signed by Tesco and Carrefour to create a joint purchasing platform with the objective of protecting their territory against the expansion of Lidl and Aldi in Central Europe and the United Kingdom, and Mercadona in Spain. A similar situation is occurring between Asda and Sainsbury in the United Kingdom. Additional evidence is the appearance of Amazon in sixth position as a worldwide retail distributor (Deloitte, "Global Powers of Retailing 2018") and its plans to acquire physical shops in Europe, as it did with Whole Food Market in the United States. Such business actions owe to the slim profit margins that these types of companies possess, a factor that also drives them to be more efficient in their supply chains. 


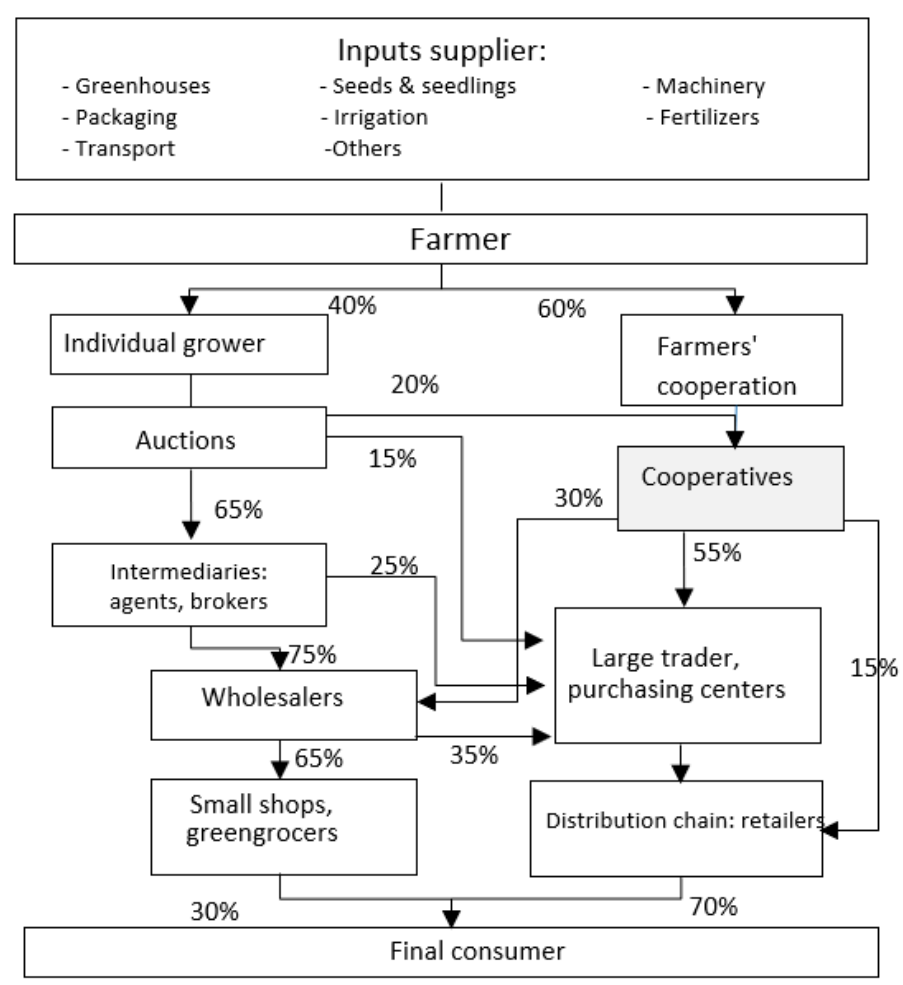

Figure 4. Spanish vegetable supply chain. \% of marketing by channel. Source: Prepared by the authors.

The companies that comprise large-scale retailers in Europe share a series of strategies in the SC. Their main objective is to raise their market share and profitability. It is important to bear in mind that this type of company, despite handling substantial volumes, obtains slim profit margins, which results in strong competition with other retailers and the tendency to adjust costs. On many occasions, the cost adjustments are transferred to suppliers. However, retailers supposedly commercialize products that satisfy the needs of their customers and that, therefore, ensure that consumer demands are passed "upstream" [56]. This type of action implies a close relationship with the other agents in the chain, which should result in a simplification of all stages of the process: production, transport, storage, and so forth. Said collaboration demands that members maintain control at all times, which is ensured by complying with standards and certifications that provide value and safety to a company's image. Although these companies act as dominant forces in the chain, it has been observed that there is a tendency to expand two-way communication with their suppliers, as the latter are those who know their products and how to manage them best.

A review of the plans of the main European distribution chains reveals the following main lines of action [57]:

- Tendency to create alliances with suppliers that favor the latter's planning processes, making supplies more reliable.

- Preference to establish contractual relationships, insofar as possible, with nearby suppliers, to develop local economies. In the case of perishables, this practice helps to favor the sale of fresh products.

- $\quad$ Use of an intermodal transport system; a difficult undertaking, above all with highly seasonal perishable products.

- Commitment to new technologies, with the aim of improving and facilitating communications between operators in the chain.

- Development of initiatives intended to reduce environmental impact: carbon footprint and water footprint. 
- $\quad$ Retailer considers that problems related to safety and quality are resolved through either the implementation of independently developed protocols (e.g., Nurture in Tesco) or ones agreed upon by various members in the sector (Global Gap, Quality Scheme for safe food-QS, International Food Standard-IFS). These standards also include social aspect add-ons.

In the sector of fresh products, one point that has been detected, which is common among all retailers, is the tendency to design short supply chains (SSCs). These chains are characterized by the existence of a more direct relationship between producer and consumer, a reduced number of intermediaries, and the minimization of transport, as the product is grown/produced in the same area where it is consumed (proximity sales), thereby creating notable local economic and social benefits [58]. In contrast, there are short proximity chains (SPCs) associated with the sale of very specific products that are not as common. Recently, various studies have questioned the link between this type of chain and local development and the reduction of environmental impact [59]. However, from a different perspective, the term "short", rather than referring to spatial proximity, could mean correctly communicating to the consumer information regarding systems of production and their location $[60,61]$. These short chains can be called "spatially extended short chains" (SESCs). In general terms, for retailers, SSCs can represent a solution to problems that affect supply networks that are more complicated and difficult to manage, as is the case in commercializing perishable products.

\subsection{The Collaborative Response of the Agrifood Company}

For the purpose of analyzing cooperation relationships maintained between horticultural production and commercialization companies in the southeast of Spain, a survey was conducted (see Annex) among 25 companies (between January and June 2019), 76\% of which were cooperatives. The average data of the sample during the last three completed seasons were the following: a marketed production of 91,726 tons per company, a turnover of $€ 103$ million, a profit of $€ 512,694$, and an asset of $€ 158$ million (the asset refers to the equity of the company according to the balance sheet).

The survey focused on analyzing the cooperation relationships in the supply chain with clients (downstream), suppliers (upstream), and other competing companies in terms of the following aspects:

(A) Production-Sustainability Programming:

1. Medium or long-term purchase-sale optimization programs to save inputs or avoid waste.

2. Actions aimed at controlling the social and environmental responsibility of your production.

(B) Production-Quality and Health Programming:

3. Agreements or collaborations to improve the quality and health safety of products.

4. Collaboration to schedule production or improvement of products.

(C) Transport-Sustainability:

5. Collaborations with the aim of optimizing loads (i.e., groupage).

6. Collaborations with the aim of optimizing routes or implementation of new transport systems.

(D) Transport-Quality and Health:

7. Agreements or collaborations to control the quality of the product in transport

(E) Facilities-Sustainability:

8. Projects to improve facilities at origin or destination with the aim of improving production sustainability.

(F) Facilities-Quality and Health: 
9. Projects to improve facilities at origin or destination with the aim of improving production quality and health.

As can be observed in Figure 5, horticultural commercialization companies have primarily been concerned with aspects related to sustainability and quality. The environmental aspects, related to production scheduling, are also an area that is drawing attention, above all, due to the growing trend to sign agreements with clients to maintain a continuous supply. In contrast, social aspects show less development. This may be because social aspects are considered to be responsibilities that are dependent on public administrations. On the other hand, most companies collaborate with clients, albeit in many cases, they do so to comply with quality standards, for example, to be able to sell. Horizontal collaboration is based on business agreements for the sale of common products of high quality. These agreements also demand collaboration with seed suppliers for the exclusive sale of specific varieties of a product. More specifically, agreements with other companies in the sector and suppliers are based on initiating projects for the reduction and optimization of production inputs. As for the aspects related to transport, sustainability is applied, in collaboration with the client, for the optimization of cargo. However, collaborating with other companies in the sector is preferred in order to test other forms of transport. Quality in transport is developed, in collaboration with the supplier, by implementing control systems to avoid generating waste, for example, due to any breaks in the cold chain. Collaboration in the area of Transport-Quality and Health with other companies in the sector, is a practice aimed at opening new markets and developing new logistics systems that guarantee product quality in the long term. Coordination in the area of Facilities-Sustainability mainly occurs with suppliers seeking to optimize greenhouses, for example, attempting to incorporate new, more sustainable energy generation systems. With regard to quality, investment in facilities is conducted with customers interested in agile management of merchandise at the destination to improve product quality and consumer service. In general terms, the most common dimensions are those related to the management of sustainability and quality in production, most of which are carried out in collaboration with customers (Figure 6). It is worth noting that sustainability surpasses quality control, a detail that contradicts recent studies in the sector [57]. Undoubtedly, in recent years, horticultural companies have devoted more attention to these areas. Table 1 displays a summary of the specific strategies, the most important, according to management dimensions in the supply chain.
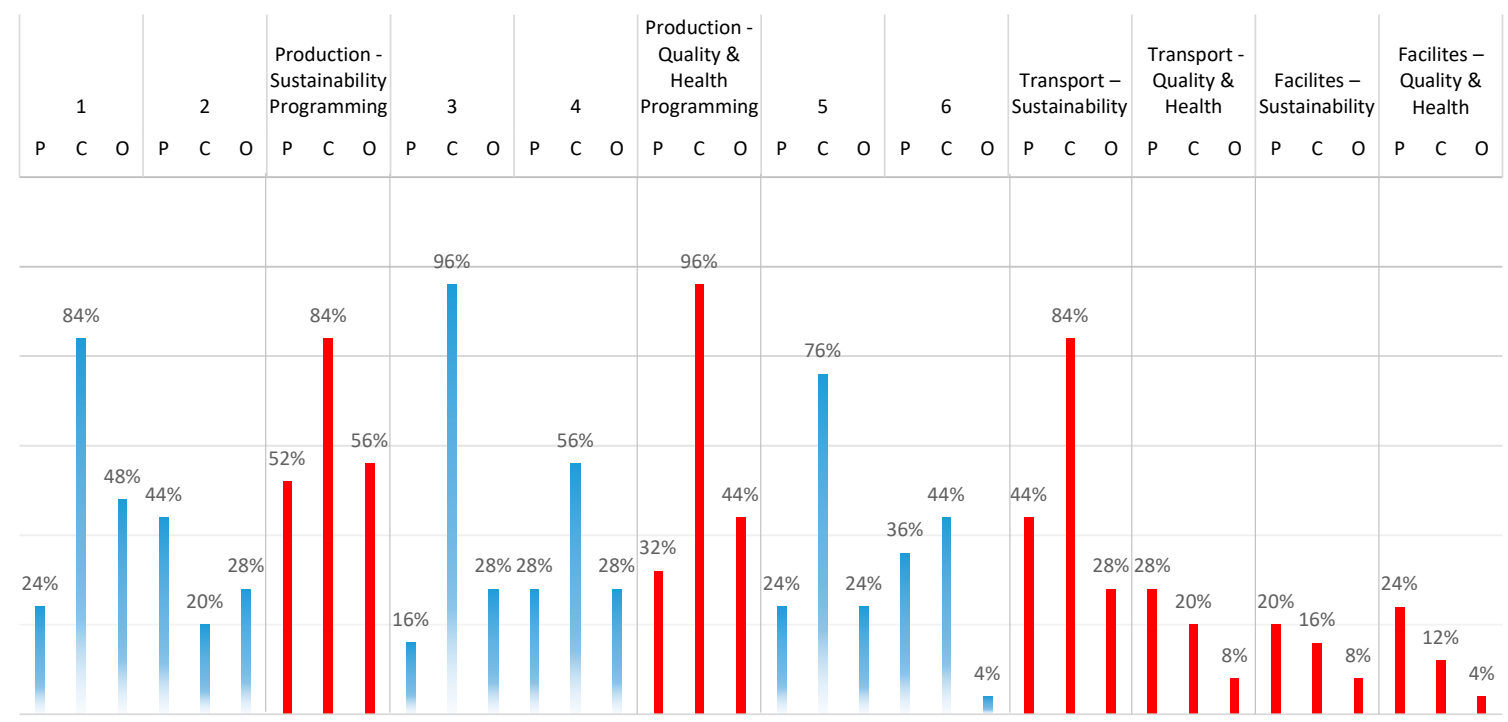

Figure 5. Survey results about collaboration in each dimension of SCM. $\mathrm{P}=$ collaboration with provider; $\mathrm{C}=$ customer; $\mathrm{O}=$ other competing company. Red colour $=$ total dimension values. Blue colour $=$ the values in each aspect within the area or dimension. 

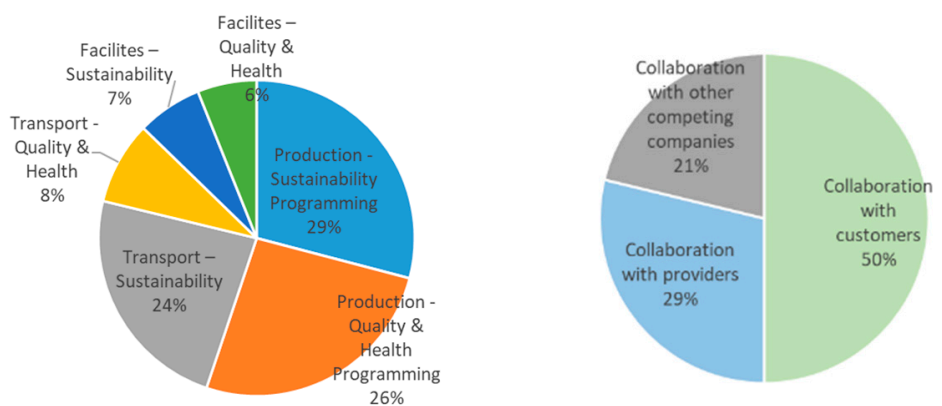

Figure 6. Survey results about type of collaboration and actors involved in SCM. Source: Own elaboration.

Table 1. Main cooperation strategies of horticultural commercialization companies in the southeast of Spain.

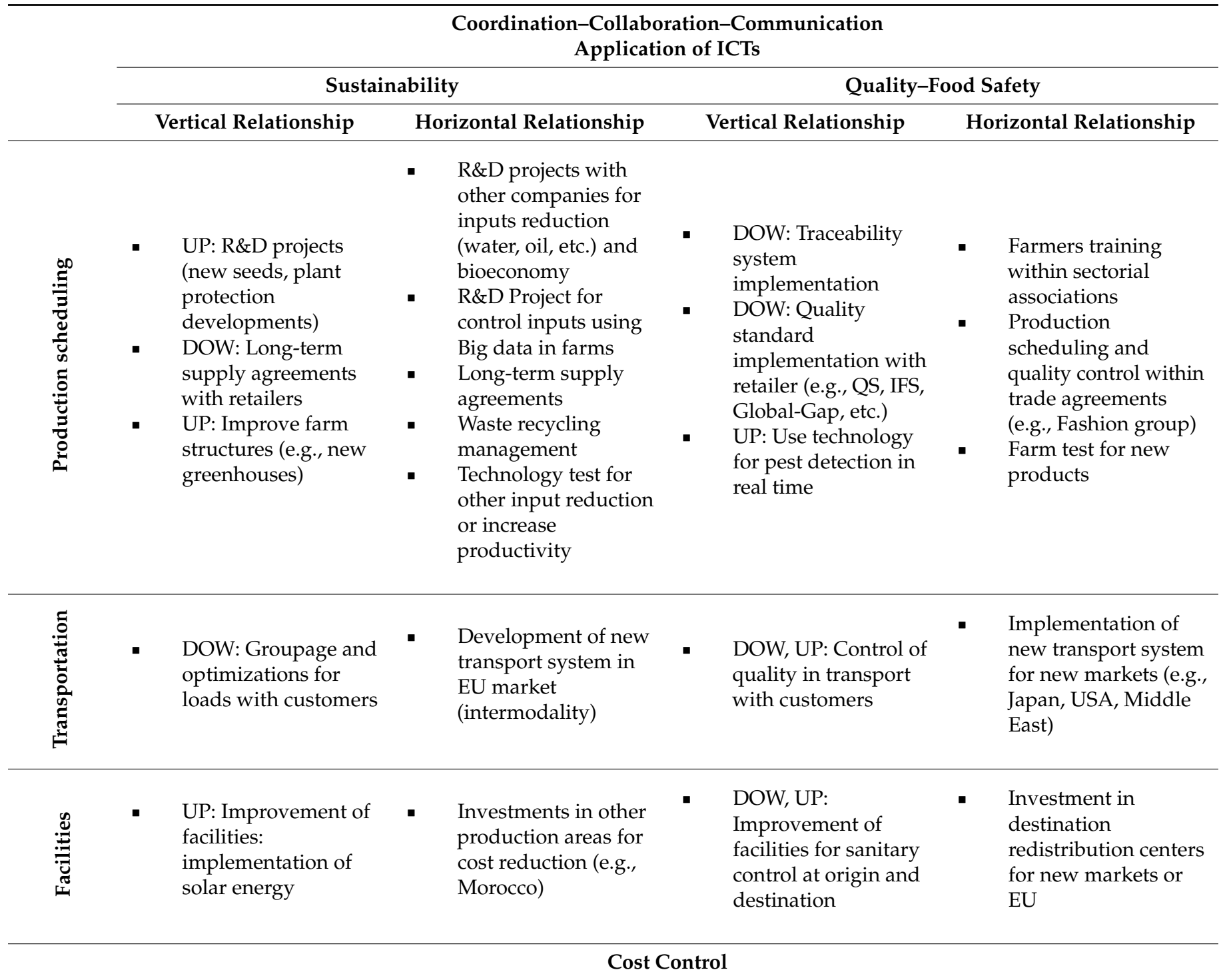

Upstream (UP); Downstream (DOW). Source: Own elaboration.

\subsection{Influence of Collaboration on the Results}

In order to corroborate the influence of collaboration, a model was utilized which linearly related the ratio of profits with respect to turnover (Profits/Turnover) to the following: (1) collaboration with suppliers (P), (2) clients (C), and (3) other competing 
companies $(\mathrm{O})$. These variables are dichotomous, taking a value of 1 if collaboration exists and 0 in other cases. This model is considered for each of the management factors. In the case of "All Dimensions", the variables $\mathrm{P}, \mathrm{C}$, and $\mathrm{O}$ were the sum of all the collaborations in the rest of the factors. In addition, the "Assets" variable was introduced as a moderator, with the objective of controlling the effect of the business dimension on business profits. This variable was applied in logarithms because it helps to analyze the effect of economies of scale [62]. There are similar studies in the literature. They seek to analyze the effect of collaboration on the performance of companies that commercialize perishables $[12,14]$. These are general models that do not distinguish between management factors within the supply chain; instead, positive effects are observed in both cases.

The results of the estimations conducted (Table 2) reveal that, despite more extensive collaboration with clients, the relationship with suppliers is the most profitable. Only in the specific case of collaboration in Transport-Sustainability (cargo groupage) does the relationship with customers appear to be profitable, albeit the influence is weak $(p<10 \%)$. By considering all the dimensions (last column), it is corroborated that the upstream relationship is the best option. These results do not discourage collaboration with clients, but rather the opening of a range of collaborations in a broader chain that includes the supplier as an important element in decisions within a supplier-supplier-customer framework. Another noteworthy aspect is the importance of the size of profitability. Indeed, a larger company (more assets) scale is an advantage that helps to better organize the management of the chain, making it possible to achieve economies of scale that result in greater profitability. Additionally, a larger size of the horticultural marketing companies will help balance relationships within the chain.

Table 2. Relationship between cooperation and results (Profits/Turnover).

\begin{tabular}{|c|c|c|c|c|c|c|c|}
\hline & $\begin{array}{c}\text { Production- } \\
\text { Sustain. }\end{array}$ & $\begin{array}{c}\text { Production- } \\
\text { Quality \& } \\
\text { Health }\end{array}$ & $\begin{array}{c}\text { Transport- } \\
\text { Sustain. }\end{array}$ & $\begin{array}{c}\text { Transport- } \\
\text { Quality \& } \\
\text { Health }\end{array}$ & $\begin{array}{c}\text { Facilities- } \\
\text { Sustain. }\end{array}$ & $\begin{array}{c}\text { Facilities- } \\
\text { Quality \& } \\
\text { Health }\end{array}$ & All Dimen. \\
\hline Intercept & $-0.115^{* * *}$ & $-0.091^{* * *}$ & $-0.109^{* * *}$ & $-0.064^{* *}$ & $-0.113^{* * *}$ & $-0.112^{* * *}$ & $-0.077^{* *}$ \\
\hline $\mathrm{P}$ & 0.014 * & 0.013 * & 0.005 & $0.029 *$ & -0.001 & 0.019 & $0.008^{* *}$ \\
\hline C & -0.014 & -0.015 & 0.006 * & -0.028 & -0.004 & -0.001 & -0.004 \\
\hline $\mathrm{O}$ & -0.003 & -0.004 & 0.005 & $0.052 * *$ & 0.001 & -0.014 & 0.001 \\
\hline Assets & $0.029 * * *$ & $0.025^{* * *}$ & $0.025^{* * *}$ & $0.016^{* *}$ & $0.028^{* * *}$ & $0.026^{* * *}$ & $0.019 * *$ \\
\hline Adj. $\mathrm{R}^{2}$ & 0.412 & 0.370 & 0.377 & 0.564 & 0.343 & 0.446 & 0.484 \\
\hline F-Stat & 5.205 & 4.531 & 4.633 & 8.787 & 4.143 & 5.832 & 6.624 \\
\hline$x^{2}(1)$ & 2.012 & 3.232 & 2.556 & 2.423 & 3.123 & 3.091 & 2.056 \\
\hline W (2) & 7.631 & 5.261 & 4.561 & 7.265 & 6.644 & 8.213 & 5.972 \\
\hline
\end{tabular}

$(1)=$ Farrar-Glaube for multicollinearity; $(2)=$ White test. ${ }^{* *}=$ significant $1 \% ;{ }^{* *}=$ significant $5 \%{ }^{*}=$ significant $10 \%$.

\section{Discussion and Conclusions}

The size of large supermarket chains continues to grow; hardly any small-size groups currently exist. This situation affects the weak link in the SC: the competition among retailers is thus transferred to the margins of the supplier. In response to this dynamic, supplier companies (mainly cooperatives) must strategically respond via horizontal growth, using concentration or cooperation, which allows improvements in innovation and in the quality of service provided to the customer. At the same time, there must also continue to be vertical collaboration. In other words, horticultural marketing companies should belong to several supply chains that include the exclusive sale of products adapted to each customer, offering a specialized and convincing solution. In the case of agriculture, aspects related to the innovation of products in collaboration with seed and biotechnology companies, and even the marketing of these products and the management of the general 
image of the sector, are also actions that commercialization companies, as a link in the supply chain, must address. This practice will help them to diversify the risk of dependence on their key customers and to escape the vicious cycle of low prices.

Indeed, it has been shown in this study that upstream collaboration can even be more profitable than collaboration with customers. This could owe to pressure from large distribution to increase profit margins, which in themselves are already very low. However, this does not imply that the relationship with the customer should be minimized. On the contrary, supply chains should expand and more closely involve the supplier's supplier. At present, the most common relationship is that which exists between the horticultural commercialization company and the retailer, which aims to improve production in terms of sustainability. If consumers recognize the efforts of the commercialization company and the retailer to respond to their demands, this relationship will have positive effects, particularly in matters of sustainability. It has been observed in recent years that aspects related to quality have been surpassed and replaced by the concept of sustainability, in environmental, social, and, of course, economic terms. In any case, depending on the demands of large distribution, there are issues that remain to be addressed. For example, there is the matter of how horticultural companies will respond to the challenge of implementing SSCs, as well as how new, more sustainable transport systems will be implemented. In this vast context, larger companies will be more capable of taking action, as it will be easier for them to optimize all their processes and achieve economies of scale, even in economies of scope.

In short, the improvement of service quality becomes much more important in all processes in a context of adjusted costs, as there is an emphasis on the social and environmental justification of production. This provides a competitive advantage to those chains that are able to implement this new paradigm, given that consumers will be willing to pay a higher price. The present work attempts to provide both a general and specific view on the subject, providing a base for relevant issues not yet covered in the analysis, which will require further research. In this regard, the incorporation of new technologies devoted to the collection, treatment, and management of information will require a rethinking and redesign of the whole of the supply chain business model [63]. For example, Big Data [52,64,65], IoT [66], Artificial Intelligence and business intelligence, BlockChain $[67,68]$, and so forth, can be applied to transform and facilitate collaboration in the framework of an intelligent supply chain, making them aspects that require further research. This is anticipated by the European Green Deal strategy in which reaching climate and sustainability targets will require investing in environmentally friendly technologies [69], as well as policies across Europe [70]. As supply chains adopt digital technologies, prior analysis on management strategies and vertical and horizontal collaborative relationships in the agrifood supply chain will need to be considered in a new light.

Author Contributions: Conceptualization, J.C.P.-M.; methodology, J.C.P.-M.; formal analysis, J.C.P.M., C.G., and L.P.-M.; investigation, J.C.P.-M., L.P.-M., C.G. and E.G.-G.; writing-original draft preparation, J.C.P.-M. and C.G.; writing-review and editing, L.P.-M.; supervision, E.G.-G., C.G. and L.P.-M.; project administration, E.G.-G. and C.G.; funding acquisition, E.G.-G. and C.G. All authors have read and agreed to the published version of the manuscript.

Funding: This research was partially funded by both the Spanish MCINN and FEDER aid [project ECO2017-82347-P] and by the European Union Horizon 2020 [Co-Fresh grant agreement no. 101000852].

Institutional Review Board Statement: Not applicable.

Informed Consent Statement: Not applicable.

Data Availability Statement: Not applicable.

Conflicts of Interest: The authors declare no conflict of interest. 


\section{References}

1. Varma, S.; Wadhwa, S.; Deshmukh, S. Implementing supply chain management in a firm: Issues and remedies. Asia Pac. J. Mark. Logist. 2006, 18, 223-243. [CrossRef]

2. Ralston, P.M.; Blackhurst, J.; Cantor, D.E.; Crum, M.R. A structure-conduct performance perspective of how strategic supply chain integration affects firm performance. J. Supply Chain Manag. 2015, 51, 47-64. [CrossRef]

3. Franco, R.P.; Phadnis, S.; Caplice, C.; Sheffi, Y. Rethinking supply chain strategy as a conceptual system. Int. J. Prod. Econ. 2016, 182, 384-396. [CrossRef]

4. Kwok, S.K.; Wu, K.K.W. RFID-based intra-supply chain in textile industry. Ind. Manag. Data Syst. 2009, 109, 1166-1178. [CrossRef]

5. Qi, Y.; Huo, B.; Wang, Z.; Yeung, H.Y.J. The impact of operations and supply chain strategies on integration and performance. Int. J. Prod. Econ. 2017, 185, 162-174. [CrossRef]

6. Yusuf, Y.Y.; Gunasekaran, A.; Adeleye, E.O.; Sivayoganathan, K. Agile supply chain capabilities: Determinants of competitive objectives. Eur. J. Oper. Res. 2004, 159, 379-392. [CrossRef]

7. Kotzab, H.; Skjoldager, N.; Vinum, T. The development and empirical validation of an e-based supply chain strategy optimization model. Ind. Manag. Data Syst. 2004, 103, 347-360. [CrossRef]

8. Mazzarol, T. Co-Operative Enterprise. A Discussion Paper \& Literature Review; Co-Operatives: Perth, WA, Australia, 2009.

9. Lyons, A.C.; Ma'aram, A. An examination of multi-tier supply chain strategy alignment in the food industry. Int. J. Prod. Res. 2014, 52, 1911-1925. [CrossRef]

10. Flynn, B.; Huo, B.; Zhao, X. The impact of supply chain integration on performance: A contingency and configuration approach. J. Oper. Manag. 2010, 28, 58-71. [CrossRef]

11. Fischer, C.; Hartmann, M.; Reynolds, N.; Leat, P.; Giha, C.R.; Henchion, M.; Albisu, L.M.Y.; Gracia, A. Factors influencing contractual choice and sustainable relationships in European agrifood supply chains. Eur. Rev. Agric. Econ. 2010, 36, 541-569. [CrossRef]

12. Mesa, J.C.P.; Gómez, E.G. Collaborative firms managing perishable products in a complex supply network: An empirical analysis of performance. Supply Chain Manag. Int. J. 2015, 20, 128-138. [CrossRef]

13. Arzu, G.; Erman, T. Supply chain performance measurement: A literature review. Int. J. Prod. Res. 2002, 48, 5137-5155. [CrossRef]

14. Gómez, E.G.; Mesa, J.C.P.; Sánchez, J.A. Internationalisation of SMEs and simultaneous strategies of cooperation and competition: An exploratory analysis. J. Bus. Econ. Manag. 2017, 17, 1114-1132. [CrossRef]

15. Dobson, P.; Waterson, M.; Davies, S.W. The patterns and implications of increasing concentration in European food retailing. J. Agric. Econ. 2013, 54, 111-125. [CrossRef]

16. Hingley, M. Power imbalance in UK agrifood supply channels: Learning to live with the supermarkets? J. Mark. Manag. 2005, 21, 63-88. [CrossRef]

17. Brandenburger, A.M.; Nalebuff, B.J. Co-Opetition; Doubleday: New York, NY, USA, 1996.

18. Dagnino, G.B.; Mariani, M. Co-Opetitive Value Creation in Entrepreneurial Contexts: An Applied Interpretative Framework. In Co-Opetition: Winning Strategies for the 21st Century; Yami, S., Castaldo, S., Dagnino, G.B., Roy, F.L., Czakon, W., Eds.; Edward Elgar: Cheltenham, UK, 2010; pp. 101-123.

19. Zerbini, F.; Castaldo, S. Stay in or get out the Janus? The maintenance of multiplex relationship between buyers and sellers. Ind. Mark. Manag. 2007, 36, 941-954. [CrossRef]

20. Wilhelm, M.M. Managing co-opetition through horizontal supply chain relations: Linking dyadic and network levels of analysis. J. Oper. Manag. 2011, 29, 663-676. [CrossRef]

21. Pérez, A.M.G.; Cervantes, C.R.; Martínez, M.G. De la cooperativa agroalimentaria a la learning netchain. Hacia un planteamiento teórico interorganizativo e interpersonal. REVESCO Rev. Estud. Coop. 2016, 121, 114-144.

22. Lazzarini, S.; Chaddad, F.; Cook, M. Integrating supply chain and network analyses: The study of netchains. J. Chain Netw. Sci. 2001, 1, 7-22. [CrossRef]

23. Yu, S.; Park, J.E.; Min, S. Factors of determining long-term orientation in interfirm relationships. J. Bus. Res. 2007, 60, 1225-1233.

24. Gurnani, H.; Erkoc, M.; Luo, Y. Impact of product pricing and timing of investment decisions on supply chain co-opetition. Eur. J. Oper. Res. 2007, 180, 228-248. [CrossRef]

25. Droge, C.; Vickery, S.K.; Jacobs, M.A. Does supply chain integration mediate the relationships between product/process strategy and service performance? An empirical study. Int. J. Prod. Econ. 2009, 137, 250-262. [CrossRef]

26. Rong, A.; Akkerman, R.; Grunow, M. An optimization approach for managing fresh food quality throughout the supply chain Int. J. Prod. Econ. 2011, 131, 421-429. [CrossRef]

27. Wassermann, S.; Faust, K. Social Network Analysis: Methods and Applications; Cambridge University Press: Cambridge, UK, 1994.

28. Rice, J.B.; Hope, R.M. Supply chain vs. Supply chain: The hype and the reality. Supply Chain Manag. Rev. 2011, 5, 47-54.

29. Peterson, C. The Learning Supply Chain: Pipeline or Pipedream? Am. J. Agric. Econ. 2002, 84, 1329-1336. [CrossRef]

30. Fawcett, S.E.; Magnan, G.M.; Mccarter, M.W. Benefits, barriers, and bridges to effective supply chain management. Supply Chain Manag. Int. J. 2008, 13, 35-48. [CrossRef]

31. Choi, T.Y.; Hong, Y. Unveiling the structure of supply networks: Case studies in Honda, Acura, Daimler Chrysler. J. Oper. Manag. 2002, 20, 469-493. [CrossRef]

32. Wu, Z.; Choi, T.; Rungtusanatham, M.J. Supplier-supplier relationships in buyer-supplier-supplier triads: Implications for supplier performance. J. Oper. Manag. 2010, 28, 115-123. [CrossRef] 
33. Yu, M.; Nagurney, A. Competitive food supply chain networks with application to fresh produce. Eur. J. Oper. Res. 2012, 224, 273-282. [CrossRef]

34. Badole, C.M.; Jain, D.R.; Rathore, D.A.; Nepal, D.B. Research and Opportunities in Supply Chain Modelling: A Review. Int. J. Supply Chain Manag. 2013, 1, 63-85.

35. Smith, D.; Sparks, L. Temperature Controlled Supply Chains. In Food Supply Chain Management; Bourlakis, M.A., Weightman, P.W.H., Eds.; Blackwell Publishing: Oxford, UK, 2004; pp. 179-198.

36. Gosling, J.; Purvis, L.; Naim, M.M. Supply chain flexibility as a determinant of supplier selection. Int. J. Prod. Econ. 2010, 128, 11-21. [CrossRef]

37. Boudahri, F.; Bennekrouf, M.; Sari, Z. Optimization and design of the transportation network of agrifoods supply chain: Application chicken meat. Int. J. Adv. Eng. Sci. Technol. 2011, 11, 213-220.

38. Mesa, J.C.P.; García, M.B.; Muñoz, L.P.; Gómez, E.G. Transport as a limiting factor for the growth of Spanish agrifood exports. Res Transp. Econ. 2019, 78, 100756. [CrossRef]

39. Ahumada, O.; Villalobos, J.R. Application of planning models in the agrifood supply chain: A review. Eur. J. Oper. Res. 2009, 195, 1-20. [CrossRef]

40. Gharehgozli, A.; Iakovou, E.; Chang, Y.; Swaney, R. Trends in global E-food supply chain and implications for transport: Literature review and research directions. Res. Transp. Bus. Manag. 2017, 25, 2-14. [CrossRef]

41. Bortolini, M.; Faccio, M.; Ferrari, E.; Gamberi, M.; Pilati, F. Fresh food sustainable distribution: Cost, delivery time and carbon footprint three-objective optimization. J. Food Eng. 2016, 174, 56-67. [CrossRef]

42. Bravo, V.L.; Caniato, F.; Caridi, M.; Johnsen, T. Collaboration for Sustainability in the Food Supply Chain: A Multi-Stage Study in Italy. Sustainability 2017, 9, 1253. [CrossRef]

43. Gold, S.; Kunz, N.; Reiner, G. Sustainable Global Agrifood Supply Chains. Exploring the Barriers. J. Ind. Ecol. 2016, 21, 249-260. [CrossRef]

44. Iakovou, E.; Vlachos, D.; Achillas, C.; Anastasiadis, F. Design of sustainable supply chains for the agrifood sector: A holistic research framework. Agric. Eng. Int. CIGR J. 2014, 5, 1-10.

45. Rajeev, A.; Pati, R.K.; Padhi, S.S.; Govindan, K. Evolution of sustainability in supply chain management: A literature review. J. Clean. Prod. 2017, 162, 299-314. [CrossRef]

46. Sharma, V.K.; Chandna, P.; Bhardwaj, A. Green supply chain management related performance indicators in agro industry: A review. J. Clean. Prod. 2017, 141, 1194-1208. [CrossRef]

47. van der Vorst, J.G.A.J. Product traceability in food-supply chains. Accredit. Qual. Assur. 2006, 11, 33-37. [CrossRef]

48. Siddh, M.M.; Soni, G.; Jain, R.; Sharma, M.K. Structural model of perishable food supply chain quality (PFSCQ) to improve sustainable organizational performance. Benchmarking Int. J. 2018, 25, 2272-2317. [CrossRef]

49. Grashuis, J. An Exploratory Study of Cooperative Survival: Strategic Adaptation to External Developments. Sustainability 2018, 10, 652. [CrossRef]

50. Lusiantoro, L.; Yates, N.; Mena, C.; Varga, L. A refined framework of information sharing in perishable product supply chains. Int. J. Phys. Distrib. Logist. Manag. 2018, 48, 254-283.

51. Cao, M.; Zhang, Q. Supply chain collaboration: Impact on collaborative advantage and firm performance. J. Oper. Manag. 2011, 29, 163-180. [CrossRef]

52. Giagnocavo, C.; Bienvenido, F.; Ming, L.; Yurong, Z.; Molina, J.A.S.; Xinting, Y. Agricultural cooperatives and the role of organisational models in new intelligent traceability systems and big data analysis. Int. J. Agric. Biol. Eng. 2017, 10, 115. [CrossRef]

53. Holmström, J.; Holweg, M.; Lawson, B. The digitalization of operations and supply chain management: Theoretical and methodological implications. J. Oper. Manag. 2019, 65, 728-734. [CrossRef]

54. Büyüközkan, G.; Göçer, F. Digital Supply Chain: Literature review and a proposed framework for future research. Comput. Ind. 2018, 97, 157-177. [CrossRef]

55. Schlüter, F.; Henke, M. Smart Supply Chain Risk Management-A Conceptual Framework. In Digitalization in Supply Chain Management and Logistics, Proceedings of the Hamburg International Conference of Logistics (HICL); Wolfgang, K., Thorsten, B., Ringle, C.M., Eds.; epubli GmbH: Berlin, Germany, 2017; Volume 23, pp. 361-380.

56. Guerrero, J.F.J.; Mesa, J.C.P.; Jiménez, J.B.; Muñoz, L.P. Considering the consumer in the design of a supply chain of perishables. Int. Food Agribus. Manag. Rev. 2018, 21, 525-542. [CrossRef]

57. Mesa, J.C.P.; Muñoz, L.P.; Barranco, M.C.G.; Giagnocavo, C. Response of fresh food suppliers to sustainable supply chain management of large European retailers. Sustainability 2019, 11, 3885. [CrossRef]

58. Sini, P. Long and short supply chain coexistence in the agricultural food market on different scales: Oligopolies, local economies and the degree of liberalisation of the global market. Eur. Sci. J. 2014, 10, 1857-7881.

59. Tregear, A. Progressing knowledge in alternative and local food networks: Critical reflections and a research agenda. J. Rural. Stud. 2011, 27, 419-430. [CrossRef]

60. Marsden, T.; Banks, J.; Bristow, G. Food Supply Chain Approaches: Exploring their Role in Rural Development. Sociol. Rural. 2000, 40, 424-438. [CrossRef] 
61. Kneafsey, M.; Venn, L.; Schmutz, U.; Balázs, B.; Trenchard, L.; Wood, T.E.; Bos, E.; Sutton, G.; Blackett, M. Short Food Supply Chains and Local Food Systems in the EU. A State of Play of Their Socio-Economic Characteristics; Joint Research Centre Institute for Prospective Technological Studies, European Commission: Brussels, Belgium, 2013.

62. Calof, J.L. The relationship between firm size and export behavior revisited. J. Int. Bus. Stud. 1994, 25, 367-387. [CrossRef]

63. di Vaio, A.; Boccia, F.; Landriani, L.; Palladino, R. Artificial Intelligence in the Agri-Food System: Rethinking Sustainable Business Models in the COVID-19 Scenario. Sustainability 2020, 12, 4851. [CrossRef]

64. Ahearn, M.C.; Armbruster, W.; Young, R. Big Data's Potential to Improve Food Supply Chain. Environ. Sustain. Food Saf. Int. Food Agribus. Manag. Rev. Spec. Issue 2016, 19, 1-18.

65. Wolfert, S.; Ge, L.; Verdouw, C.; Bogaardt, M.J. Big data in smart farming-A review. Agric. Syst. 2017, 153, 69-80. [CrossRef]

66. Verdouw, C.N.; Wolfert, S.; Beulens, A.J.M.; Rialland, A. Virtualization of food supply chains with the internet of things. J. Food Eng. 2016, 176, 128-136. [CrossRef]

67. Zhao, C.; Liu, S.; Lopez, C.; Lu, H.; Elgueta, S.; Chen, H.; Boshkoska, B. Blockchain technology in agri-food value chain management: A synthesis of applications, challenges and future research directions. Comput. Ind. 2019, 109, 83-99. [CrossRef]

68. Caro, M.P.; Ali, M.S.; Vecchio, M.; Giaffreda, R. Blockchain-Based Traceability in Agri-Food Supply Chain Management: A Practical Implementation. In Proceedings of the 2018 IoT Vertical and Topical Summit on Agriculture-Tuscany (IOT Tuscany), Tuscany, Italy, 8-9 May 2018; pp. 1-4.

69. European Commission. A European Green Deal. 2019. Available online: https://ec.europa.eu/info/strategy/priorities-2019-202 4/european-green-deal_en (accessed on 12 November 2020).

70. O'Malley, A.L.; Bronson, K.; Simone van der Burg, S.; Klerkx, L. The future(s) of digital agriculture and sustainable food systems: An analysis of high-level policy documents. Ecosyst. Serv. 2020, 45, 101183. 